\title{
PROXIMATE COMPOSITION AND FUNCTIONAL PROPERTIES OF SANDBOX SEEDS AS INFLUENCED BY PROCESSING METHODS
}

\author{
Ige, M. M.*, Gbadamosi, S. O. and Solana, O. I. \\ Department of Food Science and Technology, Obáfémi Awólówò University, Ilé-Ifè, Nigeria \\ *Corresponding author: E-mail: igemeshack@yahoo.com, Phone No.: (+234)8066385217 \\ (Received: $13^{\text {th }}$ February, 2018; Accepted: $8^{\text {th }}$ March, 2018)
}

Sandbox (Hura crepitans) seeds were processed as untreated (raw) sandbox flour (USF), cooked fermented flour (CFS), and soaked fermented flour (SFS). The three samples were defatted (with acetone) to obtain defatted untreated sandbox (DUS) flour, defatted cooked fermented (DCF) sandbox flour, and defatted soaked fermented (DSF) sandbox flour. The DSF was used to prepare sandbox protein concentration (SPC) and sandbox protein isolates (SPI). The physicochemical ( $\mathrm{pH}$ and bulk density), functional properties (water absorption capacity, WAC), oil absorption capacity (OAC), least gelation concentration (LGFC), and in-vitro protein digestibility (IVPD) of defatted untreated and soaked fermented flours and protein concentrate and isolate were determined using standard procedures. The results showed that the moisture content varied between $5.13-8.23 \%$ and that processing treatments, such as fermentation and defatting significantly (at $\mathrm{p} \leq$ 0.05 ) increased protein, ash and carbohydrate contents of sandbox seed flour. Sandbox protein isolates exhibited highest protein content $(87.49 \%)$, but the lowest crude fibre $(0.02 \%)$, fat $(1.31 \%)$ and ash $(0.47 \%)$ contents. All the samples except SPC were acidic in aqueous solution and the bulk density values ranged between $0.45 \mathrm{~g} / \mathrm{mL}-0.67 \mathrm{~g} / \mathrm{mL}$. Defatted untreated sandbox (DUS) seed flour and sandbox protein isolate (SPI) had the lowest $(1.06 \mathrm{~mL} / \mathrm{g})$ and highest $(3.38 \mathrm{~mL} / \mathrm{g})$ significantly different $(\mathrm{p} \leq 0.05)$ WAC values, respectively, while DUS and SPI had the lowest $(1.18 \mathrm{~mL} / \mathrm{g})$ and highest $(2.30 \mathrm{ml} / \mathrm{g}) \mathrm{OAC}$, respectively. The foaming capacities for DUS, DSF, SPC and SPI were 42.00, 36.84, 20.00 and 12.00\%, respectively, while emulsifying activity index ranged between $12.38-21.85 \mathrm{~m}^{2} \mathrm{~g}^{-1}$. All processing treatments were found to increase the in-vitro protein digestibility with values between 50.90 and $87.21 \%$.

Key Words: Sandbox seeds, Processing techniques, Nutrient composition, Functional properties.

\section{INTRODUCTION}

Scarcity of protein-rich food is a major problem faced by many tropical developing countries, including Nigeria. The dependency of cerealbased diets by children and pregnant women for protein and energy deprives them of essential amino acids (EAAs). In recent years, plant proteins have been playing significant roles in the same developing countries where average protein intake is less than required (Khadi et al., 2003). Due to inadequate supplies of food proteins, there has been a constant search for unconventional legumes or oil seeds as new protein sources for use as both functional supplements (Onweluzo and Nwabugwu, 2009).

Modern research has thus focused more on oil seed crops as largely unexploited sources of food crops. Sandbox (Hura crepitans) seed falls into this group of underutilized species of plants. Sandbox as an underutilized plant in Nigeria is often grown as an ornamental plant in the tropics (Allen, 2000). It belongs to the "spurge" family
(Euphorbiaceae) and is often planted in towns and villages as a cover tree. It has short densely crowned spines on the trunk and branches, the long-stalked leaves with prominent closely parallel pinnate nerves, the purple flower spikes and the large fluted flattered fruits are highly distinctive.

This tree flowers usually at the beginning of and at the end of raining season. One nut is a flattened and fluted disc with 5-20 lobes about $2.5 \mathrm{~cm}$ deep and $7.5 \mathrm{~cm}$ wide on a stout stalk. The capsule splits explosively releasing one flattened circular seed bout $18 \mathrm{~mm}$ across from each chamber (Fowomola and Akindahunsi, 2005). Seeds of sandbox are a potential source of dietary protein $(37.62 \%)$ in West Africa and Nigeria (Abdulkadir et al., 2013).

In view of the high level of protein in sandbox seed, processing the whole seed to protein rich products such as defatted flour, protein concentrate and isolate could enhance its utilization as food ingredients. However, its 
utilization as food ingredient could be limited due to the presence of anti-nutrients, such as alkaloids, oxalate, saponins, tannins, phytate and cyanide (Fowomola and Akindahunsi, 2005). Fasoyiro et al. (2006) revealed that soaking, cooking and fermentation are capable of reducing the antinutritional factors and organoleptic acceptability of the seeds (Christiana and Marcel, 2008; Omafurbe et al., 2004).

Seed proteins are required to possess the essential requisite functional properties for successful utilization in various food products or systems (Koladoye and Akanbi, 2015). These functional properties are intrinsic physicochemical characteristics which affect the behaviour of properties in food system during processing, manufacturing, storage and preparations. These properties include emulsion capacity and stability. It also includes foam capacity and stability. Other prominent properties are protein solubility, water and fat absorption capacity, bulk density (Aremu et al., 2007).

The purpose of the present investigation was to assess the effect of processing methods, such as soaking, cooking, and fermentation among others on the aforementioned properties of sandbox seeds.

\section{MATERIALS AND METHODS}

Dried seeds of sandbox (Hura crepitans) pods were collected at different locations in Obáfémi Awólówò University, Ilé-Ifè, Òsun State, Nigeria. The seeds were carefully removed from the pods and were washed under tap water to remove adhering dirts. The cleaned seeds were air-dried for about 2 hours and decorticated. The creamy white seeds of sandbox were then sun-dried for a week, packaged in polythene bags and stored in a freezer until use.

Preparation of whole and fermented sandbox flour samples

The sandbox seeds were divided into three portions and subjected to different processing treatments as shown in Figure 1. The first portion was oven-dried in a Gallenkamp oven (OVB 305, United Kingdom) at $50^{\circ} \mathrm{C}$ for 12 hours and the dried seeds were milled using harmmer mill, sieved through a $300 \mu \mathrm{m}$ sieve (Endecotts sieve, United Kingdom), then packaged using polythene bags. The sample obtained was referred to as untreated sandbox flour (USF). The second portion was prepared using a method described by Ayanwale and Kolo (2001). The seeds were cooked at atmospheric pressure for 2 hours, drained and fermented in a calabash lined with clean plantain leaves for 72 hours in the incubator (Memmert, IN30, Germany), and the fermentation was terminated by drying the cooked fermented seeds at $50^{\circ} \mathrm{C}$ (Gallenkamp over, United Kingdom) for 12 hours. It was milled for 12 hours and then hammer milled, sieved through a $300 \mu \mathrm{m}$ sieve (Endecotts sieve, United Kingdom) after which it was packaged in zip lock polythene bags. The sample obtained was referred to as cooked fermented sandbox flour (CFS).

The third portion was prepared employing same method as the second portion except that the seeds were soaked in lieu of cooking before fermenting. The seeds were soaked for 24 hours as described in the method of Nwosu (2010), drained and fermented in calabash lined with clean plantain leaves for 72 hours in incubator (Memmert, IN30, Germany), and the fermentation was terminated by drying the soaked fermented seeds at $50^{\circ} \mathrm{C}$ (Gallenkamp oven, United Kingdom) for 12 hours and then hammer milled, sieved through a $300 \mu \mathrm{m}$ sieve (Endecotts sieve, United Kingdom). This was packaged using a zip lock polythene bags. The sample obtained was referred to as soaked fermented sandbox flour (SFS). All samples were stored in a freezer (at $-20^{\circ} \mathrm{C}$ ) pending further analysis. 


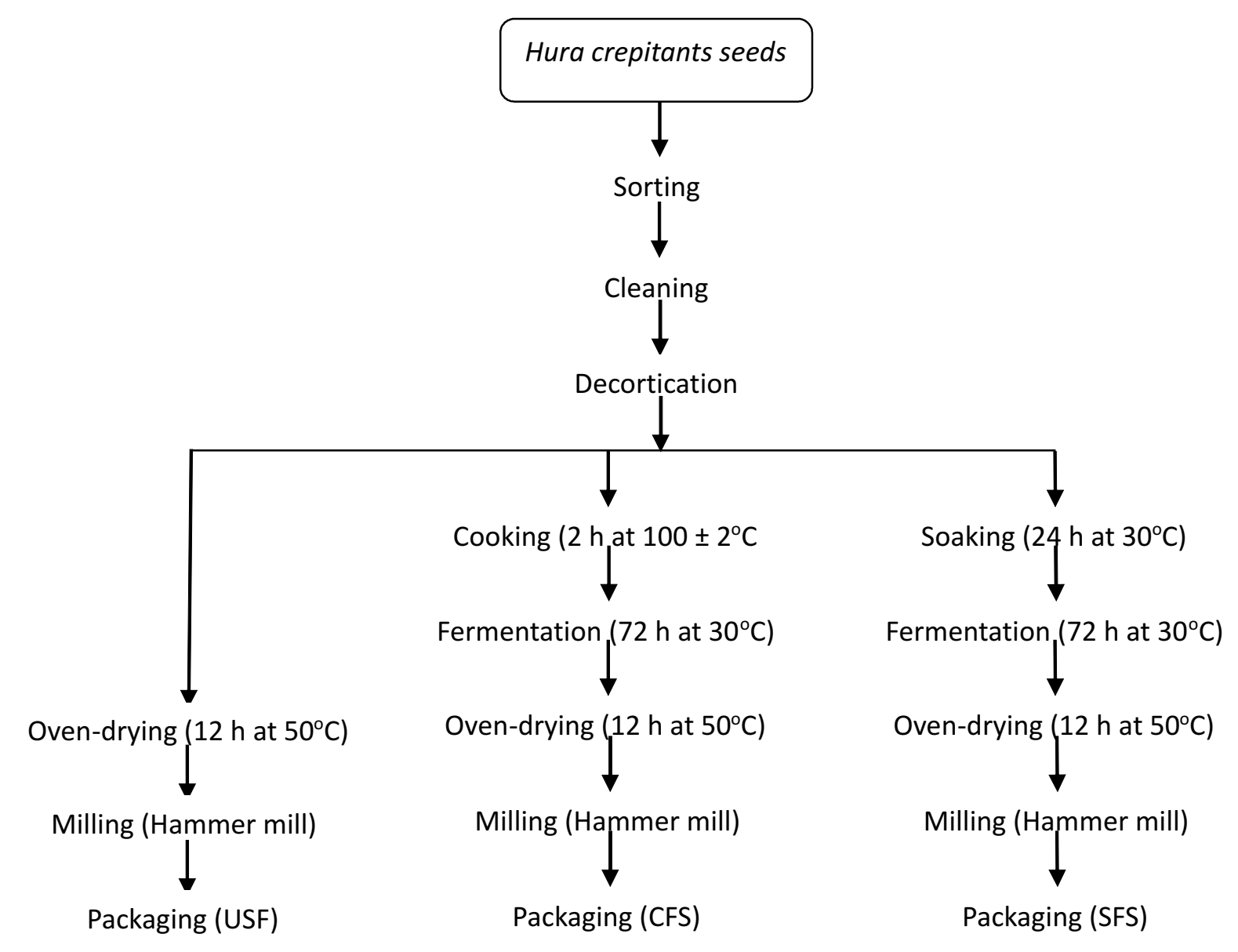

USF - Untreated sandbox flour, CFS - Cooked fermented sandbox, SFS - Soaked fermented sandbox

Figure 1: Flow chart for the production whole and fermented flours from sandbox

Preparation of Defatted Sandbox Flour

Defatted sandbox seed flours were prepared from untreated and fermented flour sample using the method of Sathe (1994) as modified by Gbadamosi et al. (2011) as shown in Figure 2. The flour sample was defatted with cold $\left(4^{\circ} \mathrm{C}\right)$ acetone using flour to solvent ratio of $1: 5 \mathrm{w} / \mathrm{v}$. The mixture was stirred over a magnetic stirred for $4 \mathrm{~h}$. The slurry was then filtered through a Whatman No. 1 filter paper. The residue was re-extracted twice in a similar fashion. The defatted flour was desolventized by drying in a fume hood at room temperature and the dried flour was finally ground in a blender (Binatone BLG-450, China) set at high speed to obtain homogeneous defatted flour. The defatted flour was stored in an air-tight plastic bottle and kept in a freezer until later used.

Preparation of Protein Concentrate

Sandbox protein concentrate was prepared from fermented defatted flour samples by a modification of the method described by Cheftel et al. (1985). A known weight $(200 \mathrm{~g})$ of the defatted flour was dispersed in $2 \mathrm{~L}$ of distilled water to give a final flour to water ratio of 1:10. The dispersion was gently stirred on a magnetic stirrer for 10 minutes. The $\mathrm{pH}$ of the resultant slurry was adjusted with $0.1 \mathrm{~N} \mathrm{HCl}$ to $\mathrm{pH} 4$ at which the protein was lest soluble. This was determined from the solubility profile of the defatted flour during preliminary investigation. 


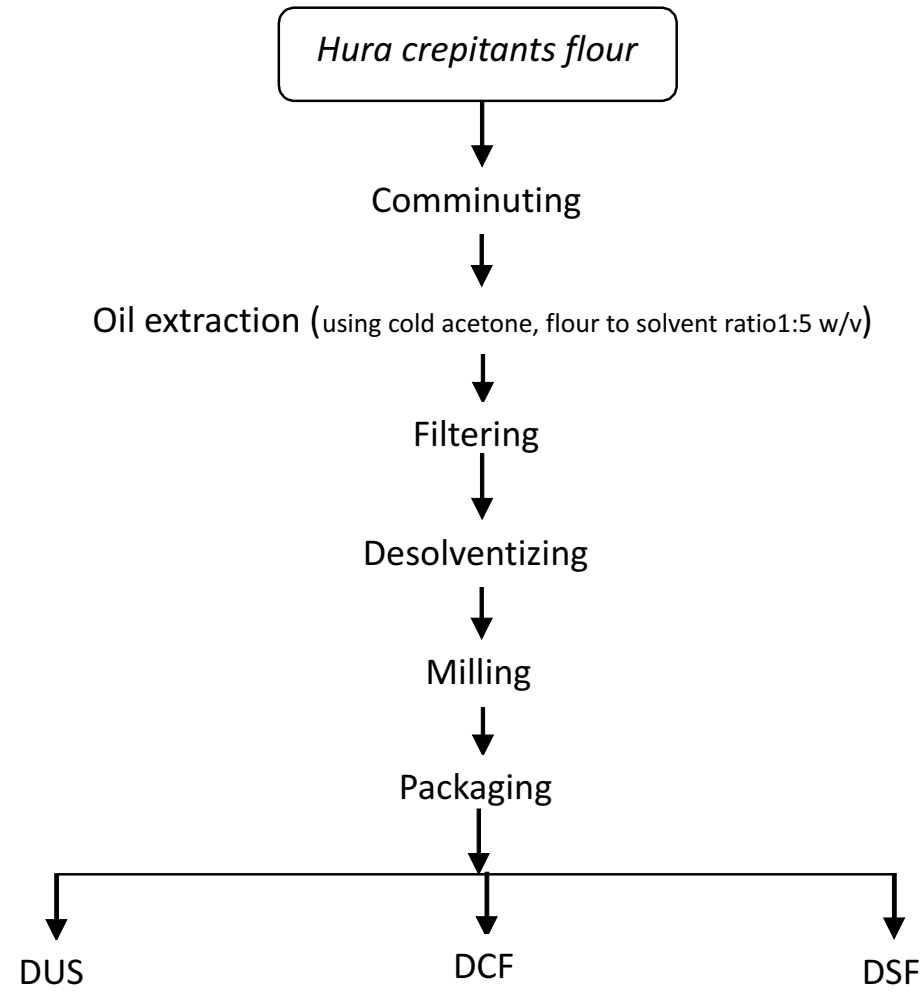

DUS - Defatted Untreated Sandbox flour,

DCF - Defatted Cooked Fermented Sandbox flour,

DSF - Defatted Soaked Fermented Sandbox flour

Figure 2: Flow chart for the production of sandbox seeds defatted flour

Source: Sathe (1994) as modified by Gbadamosi et al. (2011)

The extraction was allowed to proceed with gentle stirring for 4 hours, keeping the $\mathrm{pH}$ constant.

Soluble carbohydrates (oligosaccharides) and minerals were removed by centrifugation at 3,500 rpm for 30 minutes using MSE Harrier 15/80 Centrifuge (United Kingdom). The precipitate (concentrate) was collected and dried in an oven at $45^{\circ} \mathrm{C}$ for 8 hours. The flow chat of the process is shown in Figure 3.

Preparation of Protein Isolate

Sandbox protein isolate was prepared from fermented defatted flour by a method described by Chavan et al. (2001). A 200-g sample of the defatted flour was dispersed in $2 \mathrm{~L}$ of distilled water to give a final flour to liquid ratio of 1:10. The dispersion was gently stirred on a magnetic stirrer for 10 minutes. The $\mathrm{pH}$ of the resultant slurry was adjusted with $0.1 \mathrm{~N} \mathrm{NaOH}$ to $\mathrm{pH} 10$ at which the protein was most soluble. The extraction proceeded with gentle stirring for 4 hours keeping the $\mathrm{pH}$ constant. The nonsolubilized materials were removed by centrifugation at 3,500 rpm for 10 minutes. The proteins in the extract were precipitated by drop wise addition of $0.1 \mathrm{~N} \mathrm{HCl}$ with constant stirring until the $\mathrm{pH}$ was adjusted to $\mathrm{pH} 4.0$. The mixture was centrifuged at 3,500 rpm for 10 minutes using a centrifuge (MSE Harrier 15/80, United Kingdom) in order to recover the protein. After separation of proteins by centrifugation, the precipitate was washed twice with distilled water. The precipitated protein was re-suspended in distilled water and the $\mathrm{pH}$ was adjusted to 7.0 with $0.1 \mathrm{M} \mathrm{NOH}$, centrifuged and then freeze-dried. The freeze-dried protein was stored in air-tight glass containers at room temperature for further use. The flow chart used for the preparation of sandbox protein isolate is in Figure 4. 


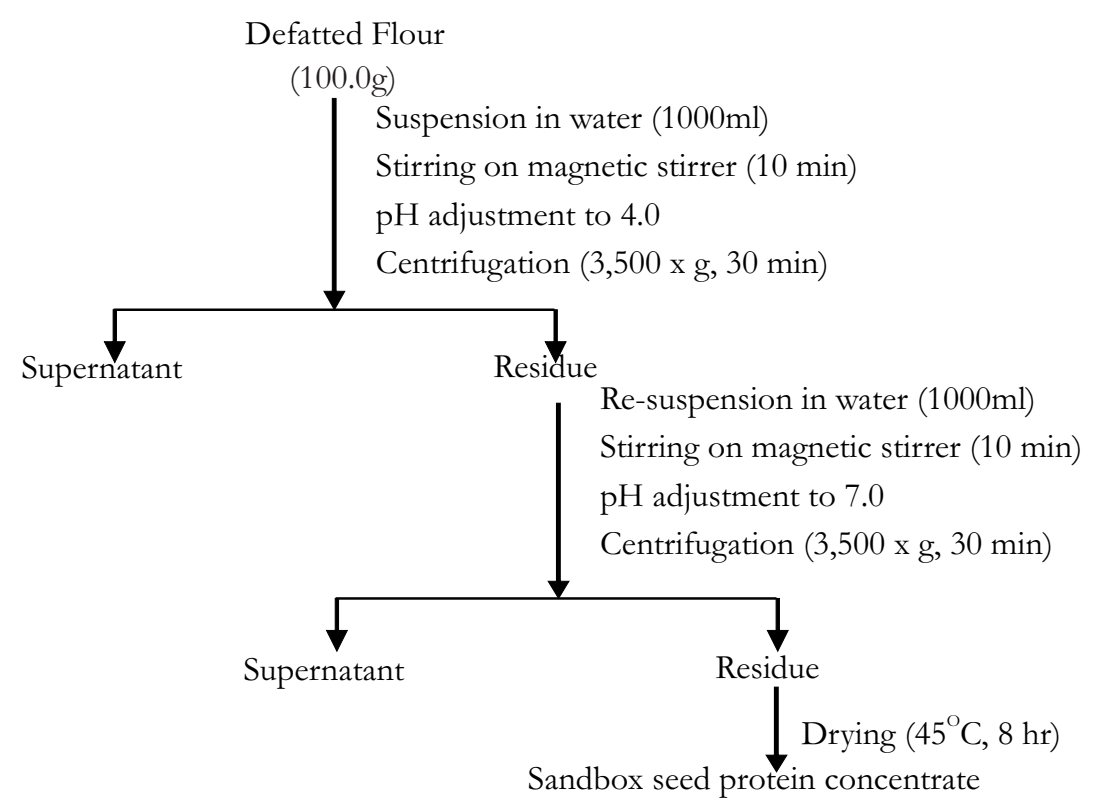

Figure 3: Scheme for the production of Sandbox protein concentrate

Adapted from Cheftel et al . (1985) as modified by Gbadamosi et al . (2011)

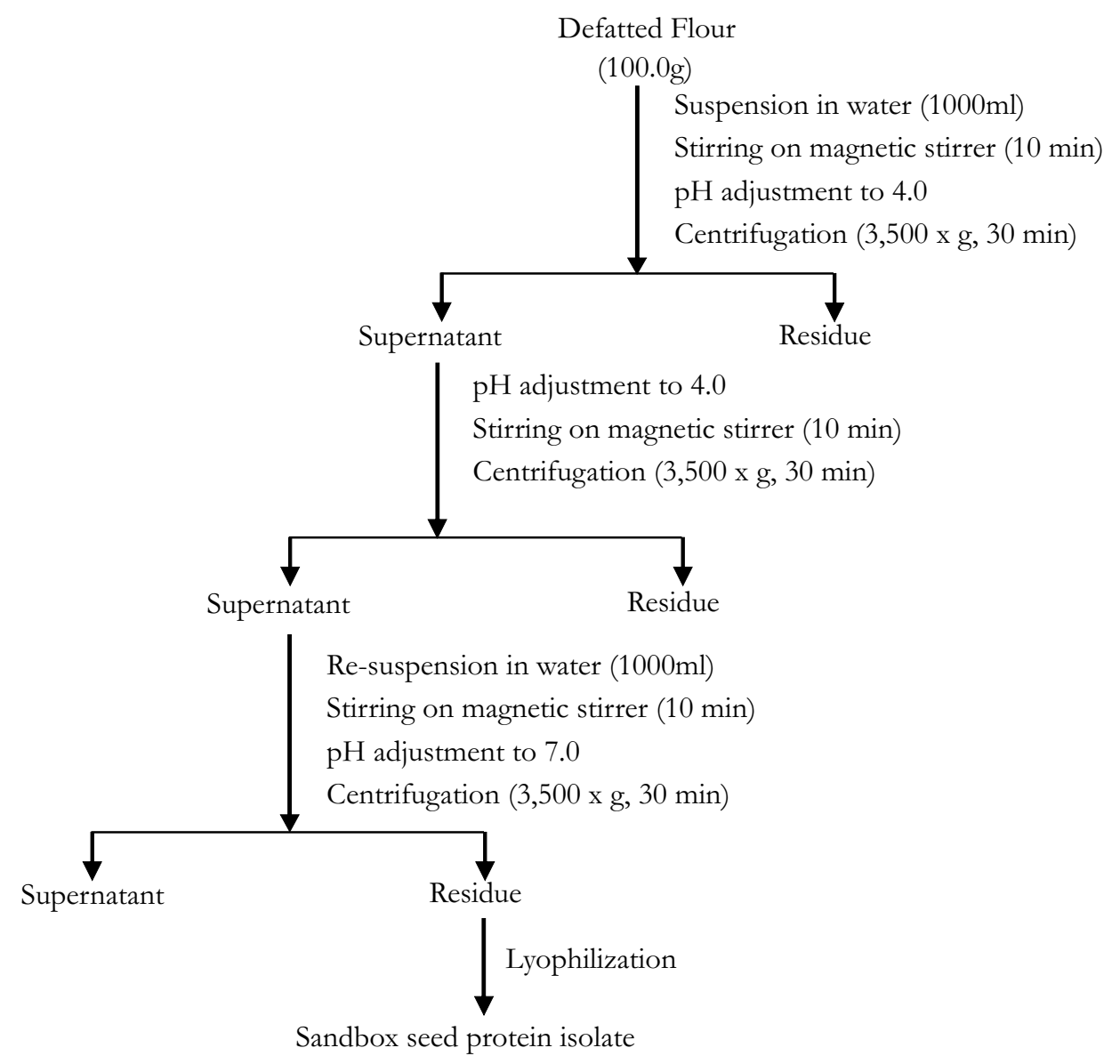

Figure 4: Scheme for the production of Sandbox protein isolate (Adapted from Chavan et al. (2001) 
Proximate Composition of Whole, Defatted Sandbox Flour, Sandbox Protein Concentrate and Isolate

Moisture contents, total ash, crude fibre and crude fat, crude protein using Kjedahl apparatus were determined for all the samples according to AOAC (2000) methods.

Physicochemical and Functional Properties Determination

\section{Bulk Density}

Bulk density was determined by the method of Okezie and Bello (1988). A $10 \mathrm{~mL}$ graduated cylinder, previously tared, was gently filled with the samples (protein concentrates and isolates). The bottom of the cylinder was gently tapped on a laboratory bench several times until there was no further diminution of the sample level after filling to the $10 \mathrm{~mL}$ mark. Bulk density was calculated as weight of sample per unit volume of sample $(\mathrm{g} / \mathrm{mL})$.

$$
\text { Bulk density }=\frac{\text { weight.of.sample. }(\mathrm{g})}{\text { volume.of sample.after.tapping. }(\mathrm{ml})}
$$

$$
\mathrm{pH}
$$

The $\mathrm{pH}$ was measured by making a $10 \% \mathrm{w} / \mathrm{w}$ suspension of the sample in distilled water. The suspension was mixed thoroughly and the $\mathrm{pH}$ (after standardizing the $\mathrm{pH}$ meter with buffer solutions of $\mathrm{pH} 7$ and $\mathrm{pH} 4$ ) was measured with a Hanna Checker pH meter (Model M11270).

\section{Water Absorption Capacity (WAC)}

The WAC was determined at room temperature and at temperatures ranging between $60-90^{\circ} \mathrm{C}$ using a combination of the AACC (1995) method and those of Sosulski (1962) and Rutkowski and Kozlowska (1981). A 2 g $\left(\mathrm{W}_{1}\right)$ sample (protein concentrate and isolate) was weighed separately into a known weight $\left(\mathrm{W}_{2}\right)$ centrifuge tube and 20 $\mathrm{mL}$ of distilled water was added to the sample. The contents were mixed for 30 seconds every 5 minutes using a glass stirring rod. After 10 minutes, it was centrifuged at $1,788 \mathrm{rpm}$ for 20 minutes using a centrifuge (0502-1 Hospibrand, USA). The supernatant was carefully decanted and then the contents of the tube were allowed to drain at a $45^{\circ}$ angle for 10 minutes and then weighed $\left(\mathrm{W}_{3}\right)$. The WAC was expressed as percentage of the volume of water absorbed by the weight of the sample as shown in equation (2):

$$
\begin{aligned}
& \text { Water absorption capacity }(\%)=\left(\frac{w_{3}-w_{2}}{+w_{1}}\right) x 100 \\
& \text { where } \mathrm{W}_{3}=\text { weight of tube } \\
& \text { centrifuging and decanting } \\
& \qquad \mathrm{W}_{2}=\text { weight of tube }+ \text { sample before } \\
& \text { centrifuging } \\
& \qquad \mathrm{W}_{1}=\text { weight of sample. }
\end{aligned}
$$

\section{Oil Absorption Capacity (OAC)}

The oil absorption capacity of the flour samples was determined by the centrifugal method elicited by Beuchat (1977) with slight modifications. One gram $\left(\mathrm{W}_{1}\right)$ of sample (protein concentration and isolate) was weighed separately into a known weight $\left(\mathrm{W}_{2}\right)$ centrifuge tube $(2 \mathrm{~cm}$ in diameter) and $10 \mathrm{~mL}$ of pure Gino oil was dispersed into the sample. The content was mixed with $10 \mathrm{~mL}$ of pure Gino oil for 60 seconds and the mixture was allowed to stand for 10 minutes at room temperature, centrifuged at $1,788 \mathrm{rpm}$ for 30 minutes using the centrifuge (0502-1 Hospibrand, USA) and the oil that separated was carefully decanted and the tubes were allowed to drain at a $45^{\circ}$ angle for 10 minutes and then weighed $\left(\mathrm{W}_{3}\right)$. Oil absorption was expressed as percentage of the volume of oil absorbed by the weight of the sample as shown in equation (3) below:

$$
\begin{aligned}
& \text { Oil absorption capacity }(\%)=\left(\frac{w_{3}-w_{2}}{w_{1}}\right) x 100 \\
& \text { where } \mathrm{W}_{3}=\text { weight of tuble after } \\
& \text { centrifuging and decanting } \\
& \mathrm{W}_{2}=\text { weight of tube }+ \text { sample before } \\
& \text { centrifuging } \\
& \qquad \mathrm{W}_{1}=\text { weight of sample. }
\end{aligned}
$$

\section{Least Gelation Concentration (LGC)}

The method of Sathe and Salunkhe (1981) was employed for the determination of gelling concentration. Sample suspensions of 1, 3, 5, 7, 9, $11,13,15,17$ and $20 \%(\mathrm{w} / \mathrm{v})$ were prepared in 5 $\mathrm{mL}$ distilled water separately into test tubes which were then heated in a boiling water bath for 1 hour followed by rapid cooling under running cold tap water. The test tubes were further cooled for 2 hours at $4^{\circ} \mathrm{C}$. Least gelling concentration was determined as the concentration when the sample form the inverted test tube did not fall down or 
slip.

Emulsifying Activity Index (EAI) and Emulsion Stability Index (ESI) of Samples

The EAI was determined by the method described earlier (Gbadamosi et al., 2011) with some modifications. About $500 \mathrm{mg}$ of the samples was dispersed in $100 \mathrm{~mL}$ of distilled water $\mathrm{NaCl}$ solution. The protein solution was mixed with 50 $\mathrm{mL}$ of pure Gino oil and the mixture was homogenized using a blender (O'Qlink SN2200, China) set at high speed for 60 seconds. Fifty microlitres of the aliquot of the emulsion was transferred from the bottom of the blender after homogenization, and mixed with $5 \mathrm{~mL}$ of $0.1 \%$ sodium odecyl sulphate (SDS) solution. The absorbance of the diluted solution was then measured at $500 \mathrm{~nm}$ using spectrophotometer (722-2000 Spectronic, England). The absorbance obtained was used to calculate the EAI as shown in equation (4) below using the method suggested by Pearce and Kinsella (1978).

Emulsifying Activity Index $\left(\mathrm{m}^{2} / \mathrm{g}\right)=$

$2 \times 2.303 \times A$

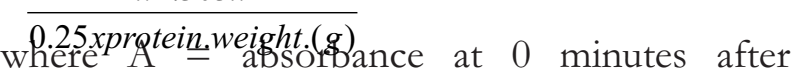
homogenization.

To determine the ESI, the emulsions was allowed to stand for 10 minutes at room temperature and the ESI was determined as described below and it was expressed based on the absorbance at 0,10 minutes and the time difference as shown in the formula:

Emulsion stability index $=$

$$
\begin{aligned}
\text { where } \mathrm{AA} & =\text { absorption at } 1 \frac{A A x \Delta t}{\mathrm{~m} A \mathrm{~A} A \text { utes }} \\
\mathrm{A} & =\text { absorbance at } 0 \text { minute } \\
\Delta \mathrm{t} & =\text { change in time }=10 \text { minutes. }
\end{aligned}
$$

Foaming capacity and stability of samples Foam capacity and foam stability was determined by a modification of the method described by Chavan et al. (2001). Approximately $2 \mathrm{~g}$ of sample was dispersed in $100 \mathrm{~mL}$ of distilled water. The solution was then homogenised for 2 minutes using a blender ( $\mathrm{O}^{\prime}$ Qlink Blender, China) at high speed and then transferred into $250 \mathrm{~mL}$ measuring cylinder. The percentage ratio of the volume increase to that of the original volume of protein solution in the measuring cylinder was calculated and expressed as foam capacity or whippability (Ogunwolu et al., 2009). Foam stability was expressed as percentage of the volume of foam remaining in the measuring cylinder to that of the original volume after 30 minutes of quiescent period.

Foaming capacity $(\%)=\quad \mathrm{x} 100$

Foaming stability $(\%)=\frac{v_{2}-v_{1}}{v_{3}} \times 100$

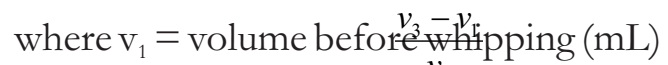

$\mathrm{v}_{2}=$ volume after whtpping $(\mathrm{mL})$

$\mathrm{v}_{3}=$ volume after standing for 30 minutes

$(\mathrm{mL})$

In vitro Protein Digestibility Determination

In vitro protein digestibility of samples was measured according to the combined methods of Saunders et al. (1973) and as modified by Chavan et al. (2001). Two hundred and fifty milligrams of the sample was suspended in $15 \mathrm{~mL}$ of $0.1 \mathrm{M} \mathrm{HCl}$ containing $1.5 \mathrm{mg}$ pepsin, followed by gentle shaking for 1 hour at room temperature. The resultant suspension was neutralized with $0.5 \mathrm{M}$ $\mathrm{NaOH}$ and treated with $4.0 \mathrm{mg}$ pancreatine in 7.5 $\mathrm{mL}$ of phosphate buffer $(0.2 \mathrm{M}, \mathrm{pH} 8.0)$. The mixture was shaller bath for 24 hours at room temperature. The mixture was then filtered using Whatman No. 1 filter paper and the residue washed with distilled water, air-dried and used for protein determination using Kjedhal procedure (AOAC, 2000) as described earlier. Protein digestibility was obtained by using the equation:

In vitro protein digestibility $(\%)=$

where $\mathrm{I}=$ protein content of sample before

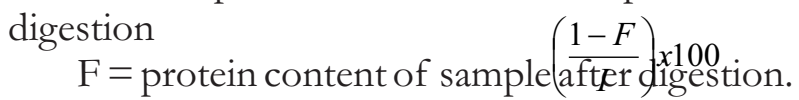

\section{RESULTS AND DISCUSSION}

Proximate Composition

The proximate composition of untreated sandbox flour (USF), defatted untreated sandbox flour 
(DUS), cooked fermented sandbox flour (CFS), defatted cooked fermented sandbox flour (DCF), soaked fermented sandbox flour (SFS), defatted soaked fermented sandbox flour (DSF), sandbox protein concentrate (SPC) and isolate (SPI) is shown in Table 1.

The moisture content of samples varied from $5.123-8.23 \%$. Defatted cooked fermented sandbox flour (DCF) exhibited the lowest (5.13\%) and USF the highest $(8.23 \%)$. The value of $8.23 \%$ obtained for USF was higher than the value reported by Abdukadir et al. (2013) for sandbox seed $(3.10 \%)$. Sandbox protein isolate (SPI) moisture content $(5.52 \%)$ was observed to be higher when compared to the moisture content of walnut protein isolates $(4.50 \%$ ) (Hua and Mao, 2012). Generally, foods high in moisture are susceptible to microbial attack. Therefore, the low moisture exhibited in sandbox flour samples may make it stable to microbial growth and thus conferred on the products extended shelf life.

Protein contents of the sandbox flour samples varied between 31.08 and $87.49 \%$. Untreated sandbox flour (USF) exhibited the least protein content $(31.08 \%)$ while SPI the highest $(87.49 \%)$. It was revealed statistically that the values of CFS $(43.78 \%)$ and SFS $(41.59 \%)$ were not significant $(p$ $\leqslant 0.05)$. The increase in protein value with fermentation time could be attributed to net synthesis of protein by fermenting organisms which might resulted in the production of some amino acids during protein synthesis (Uwagbute et al., 2000). The value of USF compare favourably with the report of Olatidoye et al. (2010) on crude protein $(31.06 \%)$ of sandbox seed flour. The protein content of USF was higher than the values reported by Okolie et al. (2012) and Oyeleke et al. (2012) on sandbox seed flour protein $(22.36 \%$ and $25.76 \%$ respectively). The protein content of SPI compared well with bambara protein isolates $(85.97 \%)$ (Eltayeb et al., 2011), safflower protein islates $(90.1 \%)$ (Ulloa et al., 2011), but was higher than conophor nut protein isolate $(80.00 \%)$ (Gbadamosi et al., 2011).

The crude fat content of the samples ranged from $1.31-48.89 \%$. Sandbox protein isolate (SPI) had the lowest value $(1.31 \%)$ while USF exhibited the highest value $(48.89 \%)$. The fat content in USF compared well with the report of Olatidoye et al. (2010) on the crude fat of sandbox seed $(43.52 \%)$, and was lower that the crude fat contents of $53.61 \%$ and $53.81 \%$ reported for sandbox seeds by Okolie et al. (2012) and Abdulkadir et al. (2013), respectively. The decrease in fat contents of fermented samples; CFS (43.41\%) and SFS $(43.67 \%)$ when compared with the whole untreated sample observed in this study may be attributed to the increased activities of the lipolytic enzymes during fermentation which hydrolysed fat components into fatty acid and glycerol (Chinma et al., 2009).

The crude fibre content of samples varied from $0.02-3.05 \%$. SPI had the lowest while DUS exhibited the highest with significant difference ( $p$ $\leqslant 0.05)$. The observed decrease in crude fibre of fermented samples in this study could be as a result of degradation of the fibre by fermenting microbes (Babalola and Giwa, 2012). The crude fibre value of USF $(1.25 \%)$ for this study compared well with the values for sandbox seed $(1.45 \%)$ by Okolie et al. (2012) and $1.21 \%$ reported by Abdulkadir et al. (2013). Fibre in foods generally offers a variety of health benefits and it is essential in reducing the risk of chronic diseases (Food Science Avenue, 2008). The ash content varied significantly $(p \leqslant 0.05)$ between $0.42-3.72 \%$ with SPI exhibiting the lowest $(0.42 \%)$ while DUS exhibited the highest value $(3.72 \%)$. The value of USF $(2.42 \%)$ agreed with the value reported by Olatidoye et al. (2010) for sandbox seed four $(2.60 \%)$. The ash content of USF was lower compared to the sandbox seed ash content reported by Okolie et al. (2012), Oyeleke et al. (2012) and Abdulkadir et al., (2013) (6.42, 3.54 and $3.55 \%$ respectively). However, high ash content implies high mineral contents which helps retard the growth of certain micro organisms and some minerals are necessary in diets for health benefits (McClements, 2003).

The carbohydrate contents of the samples varied between 2.15 and $31.55 \%$ with significant difference $(p \leqslant 0.05)$. Fermentation significantly decreased total carbohydrate content of sandbox samples as observed in USF (8.13\%), CFS (2.15\%) and SFS $(4.91 \%)$ due to enzymatic activities. The observed changes in carbohydrates with fermentation agreed with the report of 
Achinewhu and Isichei (1990), Nnam (1995), and Onweluzo and Nwagbugwu (2009) on fermented fluted pumpkin seeds, fermented cowpea and fermented millet, respectively. The apparent decrease may be attributed to increased activity of amylolytic enzymes which hydrolyze starch and other complex carbohydrates to simpler sugars. The simpler sugars then probably provided energy for the fermenting micro organism as carbon source for possible synthesis of other compounds (Kazanas and Fields, 1981).

Functional Properties of Sandbox Flours and its Protein Concentrate and Isolate

Bulk density

The bulk densities of DUS, DSF, SPC and SPI are shown in Table 2. There was no significant difference in the BD of DUS $(.067 \mathrm{~g} / \mathrm{mL})$ and SPI $(0.64 \mathrm{~g} / \mathrm{mL})$, but the values were significantly higher $(\mathrm{p} \leq 0.05)$ than those of $\operatorname{DSF}(0.54 \mathrm{~g} / \mathrm{mL})$ compared favourably with the report of Appiah et al. (2011) on bulk density of fermented breadfruit pulp flour $(0.57 \mathrm{~g} / \mathrm{mL})$. The reduction in bulk density as a result of fermentation was similar to the observation of Onimawo et al. (2003) and Elkhalalifa et al. (2005) on fermented pumpkin seed and sorghum flour respectively, where it was noticed that the fermented samples were less dense than the raw samples. Bulk density is a vital parameter that determines the suitability of flours for the ease of packaging and transportation of particulate foods as well as for infant formulations (Shittu et al., 2005).

Table 1: Proximate composition of sandbox seed whole, defatted and its protein concentrate and isolate

\begin{tabular}{|c|c|c|c|c|c|c|c|c|}
\hline Sample & USF & DUS & CFS & DCF & SFS & DSF & SPC & SPI \\
\hline Moisture (\%) & $8.23 \pm 0.04^{\mathrm{f}}$ & $6.83 \pm 0.11^{\mathrm{c}}$ & $7.62 \pm 0.02^{\mathrm{d}}$ & $5.13 \pm 0.04^{\mathrm{a}}$ & $7.74 \pm 0.05^{\mathrm{d}}$ & $5.83 \pm 0.03^{\mathrm{b}}$ & $8.03 \pm 0.04^{\mathrm{e}}$ & $5.52 \pm 0.13^{\mathrm{b}}$ \\
\hline Protein $(\%)$ & $31.08 \pm 0.62^{\mathrm{a}}$ & $51.22 \pm 0.62^{c}$ & $43.78 \pm 1.24^{\mathrm{b}}$ & $61.29 \pm 1.02^{\mathrm{d}}$ & $41.59 \pm 0.62^{\mathrm{b}}$ & $59.10 \pm 0.61^{\mathrm{d}}$ & $75.11 \pm 2.04^{\mathrm{e}}$ & $87.49 \pm 0.60^{\mathrm{f}}$ \\
\hline Fibre $(\%)$ & $1.25 \pm 0.07^{\mathrm{d}}$ & $3.05 \pm 0.07^{\mathrm{g}}$ & $0.92 \pm 0.02^{c}$ & $2.86 \pm 0.02^{f}$ & $0.88 \pm 0.01^{\mathrm{c}}$ & $2.69 \pm 0.01^{\mathrm{e}}$ & $0.14 \pm 0.01^{\mathrm{b}}$ & $0.02 \pm 0.01^{\mathrm{a}}$ \\
\hline Fat $(\%)$ & $48.89 \pm 0.01^{\mathrm{h}}$ & $3.63 \pm 0.01^{\mathrm{d}}$ & $43.41 \pm 0.01^{\mathrm{f}}$ & $3.11 \pm 0.01^{\mathrm{b}}$ & $43.67 \pm 0.01^{g}$ & $3.34 \pm 0.01^{c}$ & $3.94 \pm 0.06^{\mathrm{e}}$ & $1.31 \pm 0.01^{\mathrm{a}}$ \\
\hline Ash $(\%)$ & $2.42 \pm 0.07^{\mathrm{e}}$ & $3.72 \pm 0.02^{\mathrm{g}}$ & $2.12 \pm 0.01^{\mathrm{d}}$ & $3.17 \pm 0.06^{\mathrm{f}}$ & $1.22 \pm 0.01^{\mathrm{c}}$ & $2.12 \pm 0.02^{\mathrm{d}}$ & $0.77 \pm 0.05^{\mathrm{b}}$ & $0.47 \pm 0.02^{\mathrm{a}}$ \\
\hline Carbohydrate (\%) & $8.13 \pm 0.78^{d}$ & $31.55 \pm 0.81^{\mathrm{h}}$ & $2.15 \pm 1.26^{\mathrm{a}}$ & $24.45 \pm 1.19^{\mathrm{f}}$ & $4.91 \pm 0.57^{\mathrm{b}}$ & $26.93 \pm 0.63^{g}$ & $12.03 \pm 2.11^{\mathrm{e}}$ & $5.25 \pm 0.50^{c}$ \\
\hline
\end{tabular}

* Values reported are means \pm standard deviation of triplicate determinations. Means values with different superscript within the same row are significantly $(\mathrm{P} \leqslant 0.05)$ different.

USF: Untreated sandbox flour; DUS: Defatted untreated sandbox flour; CFS: Cooked fermented sandbox flour; DCF: Defatted cooked fermented sandbox flour; SFS: Soaked fermented sandbox flour; DSF: Defatted soaked fermented sandbox flour; SPC: Sandbox protein concentrate; SPI: Protein sandbox isolate

The bulk density of the SPC therefore suggests usefulness in infant formulations, since low bulk density flours are desirable in infant food preparation (Nelson-Quartey et al., 2007) and nutritionally it promotes digestibility off food products, particularly among children with immature digestive system (Osundahunsi and Awoh, 2002). 
Table 2: Physico-chemical and functional properties of sandbox seed defatted flours and its protein concentrate and isolate at natural $\mathrm{pH}$

\begin{tabular}{lcccc}
\hline \multicolumn{1}{c}{ Sample } & DUS & DSF & SPC & SPI \\
\hline Bulk density (g/ml) & $6.67 \pm 0.17^{\mathrm{b}}$ & $0.54 \pm 0.02^{\mathrm{ab}}$ & $0.45 \pm 0.01^{\mathrm{a}}$ & $0.64 \pm 0.01^{\mathrm{b}}$ \\
$\mathrm{pH}$ & $5.80 \pm 0.00^{\mathrm{a}}$ & $5.97 \pm 0.06^{\mathrm{b}}$ & $7.20 \pm 0.00^{\mathrm{d}}$ & $6.67 \pm 0.06^{\mathrm{c}}$ \\
Water absorption capacity $(\mathrm{ml} / \mathrm{g})$ & $1.06 \pm 0.01^{\mathrm{a}}$ & $1.34 \pm 0.08^{\mathrm{b}}$ & $3.13 \pm 0.02^{\mathrm{c}}$ & $3.38 \pm 0.01^{\mathrm{d}}$ \\
Oil absorption capacity $(\mathrm{ml} / \mathrm{g})$ & $1.18 \pm 0.03^{\mathrm{a}}$ & $1.21 \pm 0.06^{\mathrm{a}}$ & $1.33 \pm 0.06^{\mathrm{b}}$ & $2.30 \pm 0.08^{\mathrm{c}}$ \\
Emulsifying activity index $\left(\mathrm{m}^{2} \mathrm{~g}^{-1}\right)$ & $12.38 \pm 0.42^{\mathrm{a}}$ & $21.85 \pm 0.94^{\mathrm{c}}$ & $20.73 \pm 0.03^{\mathrm{c}}$ & $15.62 \pm 0.42^{\mathrm{b}}$ \\
Emulsion stability (\%) & $38.22 \pm 0.91^{\mathrm{c}}$ & $23.98 \pm 1.56^{\mathrm{b}}$ & $71.45 \pm 1.44^{\mathrm{d}}$ & $11.97 \pm 0.31^{\mathrm{a}}$ \\
Foam capacity (\%) & $42.00 \pm 0.45^{\mathrm{d}}$ & $36.84 \pm 1.74^{\mathrm{c}}$ & $20.00 \pm 1.78^{\mathrm{b}}$ & $12.00 \pm 0.52^{\mathrm{a}}$ \\
Foam stability (\%) & $35.00 \pm 1.75^{\mathrm{d}}$ & $26.32 \pm 0.43^{\mathrm{c}}$ & $9.00 \pm 1.02^{\mathrm{b}}$ & $4.00 \pm 0.13^{\mathrm{a}}$ \\
Least gelation capacity (\%) & 3.00 & 3.00 & 9.00 & 7.00 \\
IVPD (\%) & $50.90 \pm 0.62^{\mathrm{a}}$ & $61.52 \pm 0.64^{\mathrm{b}}$ & $73.33 \pm 0.69^{\mathrm{c}}$ & $87.21 \pm 1.86^{\mathrm{d}}$ \\
\hline
\end{tabular}

* Values reported are means \pm standard deviation of triplicate determinations. Means values with different superscript within the same row are significantly $(\mathrm{P} \leq 0.05)$ different.

DUS: Defatted untreated sandbox flour; DSF: Defatted soaked fermented sandbox flour; SPC: Sandbox protein concentrate; SPI: Protein sandbox isolate

$\mathrm{pH}$

The aqueous solutions of DUS, DSF, SPC and SPI had $\mathrm{pH}$ values of $5.80,5.97,7.20$ and 6.67 respectively as shown in Table 2 . The $\mathrm{pH}$ values obtained were acidic and slightly neutral, which indicated the presence of some organic acids. The increase in the $\mathrm{pH}$ of DSF over DUS agreed with the report of Omafuvbe et al. (2000) that the activities of micro organisms involved in the fermentation resulted in the release of ammonia by the organism, hence causing increase in the $\mathrm{pH}$ of the medium. The $\mathrm{pH}$ of flour suspension is important since it affects functional properties, such as solubility, emulsifying activity and foaming properties (Chavan et al., 2001; Odoemelam, 2003; Khalid et al., 2003; Gbadamosi et al., 2011).

Water Absorption Capacity (WAC)

The values of water absorption capacities of the samples were significantly different $(\mathrm{p} \leq 0.05)$ from one another and varied from $1.06-3.38$ $\mathrm{mL} / \mathrm{g}$ (Table 2). It was observed that SPI exhibited the highest water absorption capacity $(3.38 \mathrm{~mL} / \mathrm{g})$ while DUS $(1.06 \mathrm{~mL} / \mathrm{g})$ had the lowest. The water absorption capacities of SPC and SPI were higher than that of breadfruit flour $(2.19 \mathrm{~mL} / \mathrm{g})$ (Nelson-Quartey et al., 2007). The WAC of SPI was higher than that of protein isolate from the seeds of fenugreek $(1.68 \mathrm{~mL} / \mathrm{g})$ (El-El-Nasir and El-Tinay, 2007), while the WAC of DSF $(1.34 \mathrm{~mL} / \mathrm{g})$ compared well with the 1.40 $\mathrm{mL} / \mathrm{g}$ obtained for defatted white bean flour (Adebowale et al., 2005), and WAC value of DUS $(1.06 \mathrm{~mL} / \mathrm{g})$ compared favourably with the 1.12 $\mathrm{mL} / \mathrm{g}$ of soybean flour (Alfaro et al., 2004).

Adebowale et al. (2005) reported that defatted flours have higher water absorption capacities when compared to full fat samples. The absorption capacity of water by flour is a useful functionality for protein utility in aqueous food formulations, especially those involving high handling (Osungbaro et al., 2010). The matrix of protein with water is advantageous to properties, such as hydration, swelling power, solubility and gelation (Etudaiye et al., 2009).

\section{Effect of Temperature on WAC}

The effect of temperature on water absorption capacity is shown in Figure 5. The WAC values of samples with respect to temperature increase from ambient temperature to $90^{\circ} \mathrm{C}$ were DUS $(1.06-$ $1.45 \mathrm{~mL} / \mathrm{g})$, DSF $(1.34-1.45 \mathrm{~mL} / \mathrm{g})$, SPC $(3.13-$ $3.39 \mathrm{~mL} / \mathrm{g})$ and SPI $(3.38-3.82 \mathrm{~mL} / \mathrm{g})$. There were minimal increase in WAC of samples at lower temperatures $\left(30-70^{\circ} \mathrm{C}\right)$, but as temperature increased above $70^{\circ} \mathrm{C}$, water absorption capacity of the samples significantly increased $(p \leq 0.05)$. Increase in water absorption capacity of flour as a result of increase in temperature is in conformity 
with earlier report for fermented maize flour (Fasasi et al., 2007). The presence in higher amounts of carbohydrate materials and higher protein contents in defatted flour samples and protein products respectively may be attributed to the high WAC exhibited with respect to change in temperatures. This high WAC demonstrated by SPC and SPI is an advantage as the samples could be used as ingredients in soups, gravy, baked products, and as thickeners in liquid and semiliquid foods, since the samples have the ability to absorb water for improved consistency in food particularly at high temperatures.

Figure 5: Effects of temperature on water absorption capacity of defatted sandbox flours and proteins

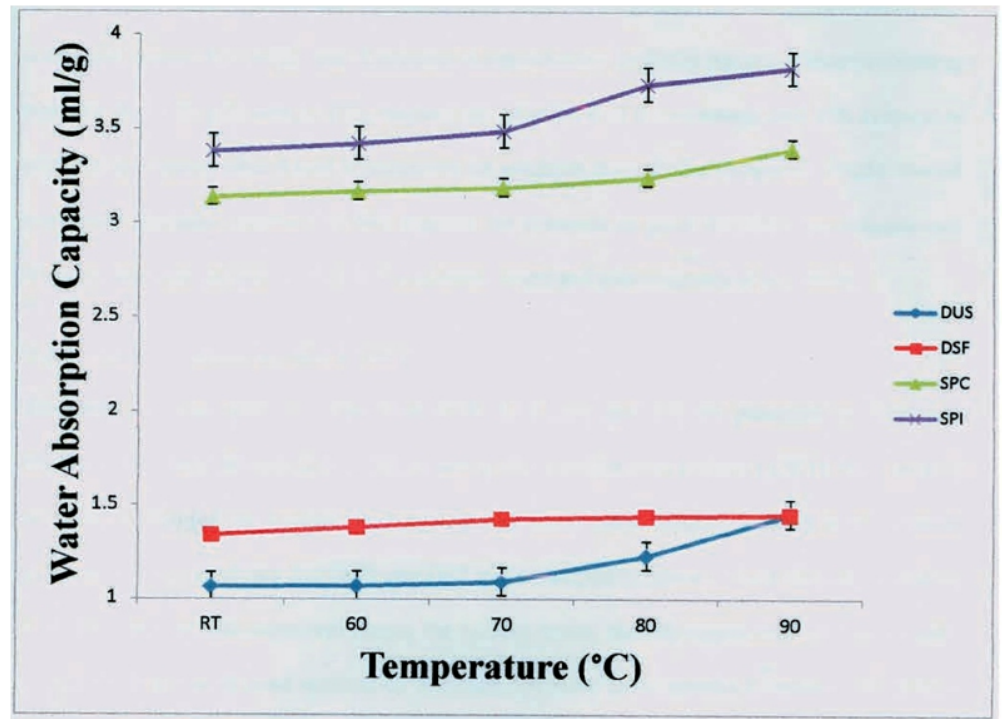

DUS: Defatted untreated sandbox flour; DSF: Defatted Soaked fermented sandbox flour; SPC: Sandbox Protein Concentration; SPI: Sandbox Protein Isolate

Oil absorption capacity (OAC)

The oil absorption capacity of samples had significantly different $(\mathrm{p} \leq 0.05)$ variation between 1.18 and $2.30 \mathrm{~mL} / \mathrm{g}$ as shown in Table 2 . The oil absorption capacity of SPI compared favourably with that of raw breadfruit flour $(2.30 \mathrm{~mL} / \mathrm{g})$ (Odoemelam, 2005), and was within the range of OAC values reported by Adebowale et al. (2005) on mucuna bean flours $(2.00-2.60 \mathrm{~mL} / \mathrm{g})$. Fat absorption is an important property in food formulations because fats improve the flavour retention and give soft texture to mouth-feel of foods (Odoemelam, 2003; Aremu et al., 2006; Ubbor and Akobundu, 2009). The value of DUS $(1.18 \mathrm{~mL} / \mathrm{g})$ which was less to DSF $(1.21 \mathrm{~mL} / \mathrm{g})$ as a result of fermentation treatment in this study, agreed with the report of Yadav et al. (2012) on the OAC of some selected cereal flour samples; sorghum $(7.03 \mathrm{ml} / \mathrm{g})$, pearl millet $(6.7 \mathrm{~mL} / \mathrm{g})$ and maize $(6.9 \mathrm{~mL} / \mathrm{g})$, that fermentation significantly $(\mathrm{p} \leq 0.05)$ increased their oil holding capacity by $15.0,22.0$ and $23.0 \%$ respectively after 36 hours of fermentation, and $7 \%$ increase in oil holding capacity after 8 hours of fermentation for sorghum flour (Elkhalalifa et al., 2005). The oil absorption capacity observed in SPI suggests the presence of good lipophilic constituents and therefore may be suitable as recipes for sausage, soups, and cakes (Aremu et al., 2006).

\section{Least gelation capacity (LGC)}

The results of the least gelation capacity of DUS, DSF, SPC and SPI are presented in Table 2. DUS and DSF had the lowest LGC $(3 \%)$ while SPC exhibited the highest LGC (9\%). Lawal et al. (2007) reported on a study on pumpkin, that lower least gelation capacity implies better gelation capacity implying that DUS and DSF had better 
gelling power. The ability of proteins to form gels and provide structural matrix for holding water, flavours, sugars, and food ingredients makes them useful application and future product developments (Aremu et al., 2006). The values of LGC obtained in this study for defatted flour samples and protein products were lower than the value $(10 \%)$ reported for soybean flour by Alfaro et al. (2004) but were within the range of values reported for African bread fruit $(6-12 \%)$ (Fasasi et al., 2007). SPC value compared favourably with LGC value pumpkin seed protein concentrate $(8.00 \%)$ reported by Atuonnwu and Akobundu (2010).

In vitro protein digestibility (IVPD)

The result of in vitro digestibility of samples is presented in Table 2. The digestibility values of samples were significantly different $(p \leqslant 0.05)$ and varied between 50.90 and $87.21 \%$. The results of protein digestibility of samples compared favourably with and were within the range of values reported by Yadav et al. (2012) for the IVPD of fermented and unfermented sorghum $(65.0-83.0 \%)$, pearl millet $(68.0-84.0 \%)$ and maize $(63.0-81.0 \%)$. The results obtained were also observed to be higher than the values obtained for uncooked soybean flour $(30.5 \%)$ (Maha et al., 2009) and conophor protein concentrate $(35.00 \%)$ (Gbadamosi et al., 2011). High digestibility in this study especially for the protein products may be attributed to decrease in the non-protein compounds especially polysaccharides as well as increase in the availability of the protein for enzymatic activities. Fermentation in this study also improved the IVPD of the defatted flour samples. This was attributed to the partial degradation of complex storage proteins into more simple and soluble products (Mohiedeen et al., 2010).

\section{Emulsifying properties}

The results of emulsifying activity index (EAI) and emulsion stability index (ESI) for sandbox flour samples are shown in Table 2. The values of EAI for the samples varied from $12.38-21.85$ $\mathrm{m}^{2} / \mathrm{g}$ and were significantly different $(\mathrm{p} \leq 0.05)$. DSF $\left(21.85 \mathrm{~m}^{2} / \mathrm{g}\right)$ and DUS $\left(12.38 \mathrm{~m}^{2} / \mathrm{g}\right)$ had the highest and lowest EAI respectively. The emulsion stability index (ESI) with significantly different $(\mathrm{p}$ $\leq 0.05)$ values varied between 11.97 and $71.45 \%$.
The highest stability occurred in SPC $(71.45 \%)$, while the least was observed in SPI $(11.97 \%)$. This study revealed that both SPC and SPI had lower emulsion capacity compared to DSF. This result was in agreement with earlier observation by Atuonnwu and Akobundu (2010) who observed that the emulsion capacities of defatted pumpkin seed flour $(22.0 \%)$ was higher compared to its protein concentrate ad isolate $(5.0 \%$ and $1.0 \%$ respectively). According to Ogunwolu et al. (2009) and Hua and Mao (2012), emulsifying capacity of defatted cashew nut powder and defatted walnut flour (24.63\% and $53.28 \%$ respectively) exhibited the highest values, while cashew nut protein concentrate and isolate $(12.48 \%$ and $50.01 \%$ respectively) were lower as compared to the defatted flour. The preparation conditions of the samples can also affect their emulsifying properties as reported by Atuonnwu and Akobundu (2010), as difference in residual lipid content and composition can conditionally result from the defatting processes which are responsible for the modified protein functionality (Wu and Wang, 2003).

\section{Foaming properties}

The foam capacity of the samples varied between $12.00-42.00 \%$ with significant difference $(\mathrm{p} \leq$ $0.05)$ as shown in Table 2. It was observed that DUS $(42.00 \%)$ had the highest FC while SPI $(12.00 \%)$ had the lowest FC. The foam stability of the samples were between $4.00-35.00 \%$ with SPI having the lowest FS while DUS exhibited the highest value and were significantly different. Adebowale et al. (2005) explained that the low foam capacity may be attributed to high levels of globular proteins, which resist surface deaturation. Foaming result obtained for this study revealed that DUS and DSF had better capacities and stabilities than the protein products. This agrees with the observations of Atuonnwu and Akobundu (2010) on pumpkin seed protein concentrate and isolate which exhibited poor foamability, while pumpkin seed flour had a better foaming capacity and stability. This could be attributed to the protein solubility which has an important influence on the foaming behaviour of proteins (L'Hocine et al., 2006). Also, DUS $(42.00 \%)$ and DSF (36.84\%) had higher foaming capabilities than praseed flour $(32.6 \%)$ reported by Choonhahirun (2010) and conophor defatted 
flour $(24.17 \%)$ as reported by Gbadamosi et al. (2011). The foam capacity of sandbox seed concentrate $(20.00 \%)$ and isolate $(12.00 \%)$ were lower than conophor protein concentrate $(35.00 \%)$ and isolate $50.00 \%)$ reported by Gbadamosi et al. (2011), and walnut protein concentrate $(38.78 \%)$ and isolate $(46.34 \%)$ reported by Hua and Mao (2012). The results suggest that sandbox seed protein might not be suitable as whipping agents in food formulations, while the defatted flours could perform well as aerating agents in whipped toppings, frozen desserts and sponge cakes.

\section{CONCLUSION}

This study examined the effect of processing on nutrient composition, physicochemical and functional properties of sandbox seed flour as well as its in vitro protein digestibility (IVPD). The result of proximate composition revealed that fermenting and defatting significantly increased the protein contents of sandbox flour samples. Sandbox protein concentrates and isolates demonstrated high water and oil absorption capacities for possible use as flavour retainers and in bakery mixes, while defatted untreated and soaked fermented sandbox flours exhibited high gelling powers. Defatted soaked fermented sandbox flour showed good emulsifying and foaming capabilities for possible use as emulsifying and foaming agents especially in icecream and whipped toppings. The high in-vitro protein digestibility of the sandbox seed proteins means that a high percentage of the sandbox seed proteins can be digested by the proteolytic enzymes of the digestive system.

\section{REFERENCES}

Abdulkadir, M.N., Amoo, I.A. and Adesina, A.O. (2013). Chemical composition of Hura crepians seeds and antimicrobial activities of its Oil. International Journal of Science and Research (IJSR), 2(3): 440-445.

Achinewhu, S.C. and Isichei, M.O. (1990). The nutritional evaluation of fermented fluted pumpkin seeds (Telferia accidentalis hook). Discovery Innovation, 2:62-65.

Adebowale, Y.A., Adeyemi, I.A. and Oshodi, A.A. (2005). Functional and physico-chemical properties of flours of six mucuna species. African Journal of Biotechnology,
4(12): 1461-1468.

Alfaro, M.J., Alvarez, I., Khor, E.L. and Padika, F.C. (2004). Functional properties of protein products from Barinus nut. American Journal of Nutrition, 54: 223228.

Allen, T.F. (2000). Hura crepitans L. The encyclopaedia of pure material medical. Homeopathe International, New Delhi, India, pp. 1-2.

American Association of Cereal Chemist (AACC) (1995). Approved methods of AACC (9th ed., 1 and 2), St. Paul MN.

AOAC (2000). 'Official methods of analysis'. Association of Official Analytical Chemicals, Washington, D.C.

Appiah, F., Oduro, I. and Ellis, W.O. (2011). Functional properties of Artocarpus altilis pulp flour as affected by fermentation. Agriculture and Biology Journal of North America, 10:653-657.

Aremu, M.O., Olaofe, O. and Akintayo, E.T. (2007). Functional properties of some Nigerian varieties of legume seed flours and flour concentration effect on foaming and gelation properties. Journal of Food Technology, 5(2):109-115.

Aremu, M.O., Olonisakin, A., Atolaye, B.O. and Ogbu, C.F. (2006). Some nutritional and functional studies of Prosopis Africana. Electronic Journal of Environmental Agricultural and Food Chemistry, 5(6): 1640-1648.

Atuonnwu, A.C. and Akobundu, E.N.T. (2010). Functional and pasting properties of pumpkin (Cucurbita pepo) seed products. Journal of Agricultural; and Veterinary Sciences, 2:36-47.

Babalola, R.O. and Giwa, E.O. (2012). Effect of fermentation on nutritional and antinutritional properties of fermenting soybeans and the antagonistic effect of the fermenting organism on selected pathogens. International Research Journal of Microbiology (IRJM), 3(10): 333-338.

Beuchat, L.R. (1977). Functional and electrophoretic characteristics of succinylated peanut flour protein. Journal of Agricultural Food Chemistry,

Chavan, U., Mckenzie, D. and Shahidi, F. (2001). Functional properties of protein isolates 
from beach pea (Lathyrus maritimus L.). Food Chemistry. 74, 177-187.

Cheftel, J.C., Cuq, J.L. and Lorient, D. (1985). Food Chemistry: Amino Acids, Peptides and Proteins (edited by Fennema, O.R.). New York, NY: Marcel Dekker, pp. 127228.

Chinma, C.E., Adewuyi, O. and Abu, O.J. (2009). Effect of germination on the chemical, functional and pasting properties of flours from brown and yellow varieties of tiger nut (Cyperus esculentus). Food Research International, 42: 1104-109.

Choonhahirun, A. (2010). Proximate composition and functional properties of preseed (Elateriospermun tapos Blume) flour. African Journal of Biotechnology, 9, 5946-5949.

Christiana, N.E. and Marcel, J.I. (2008). Effects of the nutritional and anti-nutritional content of African Locust Bean (Parkia biglobosa benth) seed. Pakistan Journal of Nutrition, 7: 214-217.

Elkhalalifa, A.E.O., Schiffler, B. and Bernhardt, R. (2005). Effect of fermentation on the functional properties of sorghum flour. Food Chemistry, 92: 1-5.

El-Nasir, N.A. and El-Tinay, A.H. (2007). Functional properties of fenugreek (Trigonella foenumgraecum) protein concentrate. Food Chemistry, 103: 582589.

Eltayeb, A.S.M., Abou-Arab, A.A., Ali, O.A. and Abu-Salem, F.M. (2011). Chemical composition and functional properties of flour and protein isolate extracted from Bambara groundnut (Vigna subterranean). African Journal of Food Science, 5(2): 82-90.

Etudaiye, H.A., Nwabueze, T.U. and Sanni, L.O. (2009). Quality of fufu processed from cassava mosaic disease (CMD) resistant varieties. African Journal of Food Science, 3(3): 61-67.

Fasasi, O.S., Eleyinmi, A.F. and Oyarekua, M.A. (2007). Effect of some traditional processing operation on the functional properties of African bread fruit seed (Treculia Africana) flour, LWT-Food Science Technology, 40:153-159.

Fasoyiro, S.B., Ajibade, S.R., Omole, A.J.,
Adeniyan, O.N. and Farinde, E.O. (2006). Proximate, minerals and ant-nutritional factors of some under-utilized grain legumes in the South West Nigeria. Journal of Nutrition and Food Science, 36(1):18-23.

Food Science Avenue (2008). Crude fibre. www.fooscience-avenue.com/2008/04/ crude-fibre.html?m=1 Assessed February 2014.

Fowomola, M.A. and Akindahunsi, A.A. (2005). Protein quality indices of sandbox (Hura creptans) seeds. Journal of Food, Agriculture and Environment, 3(3\&4): 16-19.

Gbadamosi, S.O., Abiose, S.H. and Aluko, R.E. (2011). Amino acide profile, protein digestibility, thermal and functional properties of Conophor nut (Tetracarpidium conophorum) defatted flour, protein concentrate and isolates. International Journal of Food Science and Technology, 47: 731-739.

Hua, Y. and Mao, X. (2012). Composition, structure and functional properties of protein concentrates and isolates produced from walnut (Juglans regia L.). International Journal of Molecular Sciences, 13: 1561-1581.

Kazanas, N. and Fields, M.L. (1981). Nutritional improvement of sorghum by fermentation. Journal of Food Science, 49:819-821.

Khadi, E.K., Babiker, E.E. and El-Tinay, A.H. (2003). Solubility and functional properties of sesame seed protein as influenced by $\mathrm{pH}$ and/or salt concentrate. Food Chemistry, 82(3):361-366.

Koladoye, A.O. and Akanbi, C.T. (2015). Functional and sensory properties of fermented locust bean seeds using optimized pre-fermentation conditions. Ife Journal of Technology, 23(2): 26-39.

Lawal, O.S., Adebowale, K.O. and Adebowale, Y.A. (2007). Functional properties of native and chemically modified protein concentrates from Bambara groundnut. Food Research International, 40(8): 10031011.

L'Hocine, L. Boye, J.I. and Arcand, Y. (2006). Composition and functional properties of 
soy protein isolates prepared using alternative defatting and extraction procedures. Journal of Food Science, Food Chemistry and Toxicology, 71(3): 137-145.

Maha, A.M., Abdullahi, H.E., Isam, A.A. and Elfadil, E.B. (2009). Supplementation of pearl millet with soybean: Changes in protein digestibility, amino acid composition and sensory quality during processing. Electronic Journal of Environmental, Agricultural and Food Chemistry, 8:1068-1076.

McClements, D.J. (2003). Analysis of Food Products. www.people.umass.edu / $\neg$ mcclemen/ 581Ash\&Minerals.html Assessed February 2014.

Mohiedeen, I.E., Tinay, A.H.E., Elkhalya, A.E.O., Babiker, E.E. and Mallasiy, L.O. (2010). Effect of fermentation on in vitro protein digestibility, protein fractions and amino acids composition of maize (Zea mays Linnaus) cultivars. Electronic Journal of Environmental and Agriculture Food Chemistry, 9: 838-847.

Nelson-Quartey, F.C., Amagloh, F.K., Oduro, I. and Ellis, W.O. (2007). Formulation of an infant food based on breadfruit (Artocarpus altilis) and breadnut (Artocarpus camansi). Acta Horticulturae, 757:212-224.

Nnam, N.M. (1995). Evaluation of nutritional quality of fermented cowpea (Vigna unguiculato) flours. Ecology of Food and Nutrition, 33:273-279.

Nwosu, J.N. (2010). Effect of soaking, blanching and cooking on the anti-nutritional properties of asparagus been (Vigna sesquipedis) flour. Nature and Science, 8(8): 163-167.

Odoemelan, S.A. (2003). Chemical composition and functional properties of conophor nut (Tetracarpidium conophorum) flour. International Journal of Food Science Technology, 38:729-734.

Odoemelan, S.A. (2005). Functional properties of raw and heat processed jackfruit (Artocarpu heterophyllus) flour. Pakistan Journal of Nutrition, 4(6): 366-370.

Ogunwolu, S.O., Henshaw, F.O., Mock, H., Snatros, A. and Awonorin, S.O. (2009).
Functional properties of protein concentrates and isolates produced from cashew (Anacardium occidenate L.) nut. Food Chemistry, 115: 852-858.

Okezie, B.O. and Bello, A.B. (1988). Physicochemical and functional properties of winged bean flour and isolate compared with soy isolate. Journal of Food Science, 53(2): 450-454.

Okolie, P.N., Uaboi-Egbenni, P.O. and Ajekwene, A.F. (2012). Extraction and quality evaluation of sandbox tree seed (Heura crepitan) oil. World Journal of Agricultural Sciences, 8(4): 359-365.

Olatidoye, O.P., Adeleke, A.E., Adegbite, S.A. and Sobowale, S.S. (2010). Chemical composition and nutritional evaluation of sandbox (Hura creption) seed flour for domestic consumption and industrial utilization in Nigeria. Journal of Medical and Applied Biosciences, 2: 72-83.

Omafuvbe, B.O., Falade, O.S., Osuntogun, B.A. and Adewusi, S.R.A. (2004). Chemical and biochemical changes in African locust bean (Parkia biglobosa) and melon (citrullus vulgaris) seeds during fermentation to condiments. Parkistant Journal of Nutrition. 3(3): 140-145.

Omafuvbe, B.O., Shonukan, O.O. and Abiose, S.H. (2000). Microbiological and biochemical changes in the traditional fermentation of soybean daddawa - a Nigerian food condiment. Food Microbiology, 17:469-474.

Onimawo, I.A., Nmerole, E.C., Idoko, P.I. and Akubor, P.I. (2003). Effects of fermentation on nutrient content and some functional properties of pumpkin seed (Telfaria occidentalis). Plant Foods for Human Nutrition, 58(3): 1-9.

Onweluzo, J.C. and Nwabugwu, C.C. (2009). Fermentation of millet (Pennisetum americanum) and pigeon pea (Cajamus cajan) seeds for flour production: Effects on composition and selected functional properties. Pakistan Journal of Nutrition, 8:737-744.

Osundahunsi, O.F. and Awoh, O.C. (2002). A preliminary study on the use of tempeh based formula as a weaning diets in Nigeria. Plant Foods for Human 
Nutrition, 57:365-376.

Osungbaro, T.O., Jimoh, D. and Osundeyi, E. (2010). Functional and pasting properties of composite cassava-sorgium flour meals. Agriculture and Biology Journal of North America, 1(4): 715-720.

Oyeleke, G.O., Olayiwola, O.A. and Latona, D.F. (2012). Chemical examination of sandbox (Hura crepitans) seed: Proximate, elemental and fatty acid profile. IOSR Journal of Applied Chemistry (IOSRJAC), 1(2): 10-13.

Pearce, K.N. and Kinsella, J.E. (1978). Emulsifying properties of proteins. Evaluation of a turbidimetric technique. Jounral of Agricultural Food Chemistry, 26(3): 716-723.

Rutkowski, A. and Koslowska, H. (1981). Food preparation from plant proteins. Wydamnictwo Naukowo-Techniczne (WNT), Warszawa, Poland, pp. 318-334.

Sathe, S.K. (1994). Solubilization and electrophoretic characterization of cashew nut (Anacardium occidentale) proteins. Food Chemistry, 51:319-324.

Saunders, R.M., Connor, M.A., Booth, A.N., Bickoff, E.N. and Kohier, C.O. (1973). Measurement of digestibility of alfalfa protein concentrate by in vitro and in vivo methods, Journal o Nutrition, 103:530535.

Shittu, T.A., Sanni, L.O., Awonorin, S.O., MaziyaDixon, B. and Dixon, A. (2005). Use of multivariate techniques in studying flour making characteristics of some cassava mosaic disease resistant cassava clones. African Crop Science Conference Proceeding, 7: 621-630.

Sosulski, F.W. (1962). The centrifuge method of determining water absorption in hard red spring wheats. CereaL Chemistry, 39:334337.
Ubbor, S.C. and Akobundu, E.N.T. (2009). Quality characteristics of cookies from composite flours of watermelon seed, cassava and wheat. Pakistan Journal of Nutrition, 8(7): 1097-1102.

Ulloa, A.J., Rosas-Ulloa, P. and Ulloa-Rangel, B.E. (2011). Physicochemical and functional properties of a protein isolate produced from safflower (Carthamus tinctorius L.) meal by ultra filtration. Journal of Science and Food Agriculture, 91:572-577.

Uwagbute, A.C., Iroegbu, C.U. and Eke, O. (2000). Chemical and sensory evaluation of germinated cowpea (Vigna unguiculata) and their products. Food Chemistry, 68: 141-146.

Yadav, N., Singh, A. and Shorma, S. (2012). Effect of fermentation on physicochemical properties and in vitro starch and protein digestibility of selected cereals. International Journal of Agricultural Food Science, 2(3): 66-70.

Wu, Y. and Wang, T. (2003). Total and polar lipids in soybean protein meals. Journal of American Oil Chemists' Society, 80(10): 983-985. 